\title{
Relevance of miR-223 as Potential Diagnostic and Prognostic Markers in Cancer ${ }^{\dagger}$
}

\author{
Faisal Aziz *, Abhijit Chakraborty (D, Imran Khan and Josh Monts
}

Citation: Aziz, F.; Chakraborty, A.;

Khan, I.; Monts, J. Relevance of

miR-223 as Potential Diagnostic and

Prognostic Markers in Cancer. Biology

2022, 11, 249. https://doi.org/

10.3390/biology11020249

Academic Editor: Hang Fai Kwok

Received: 20 December 2021

Accepted: 3 February 2022

Published: 6 February 2022

Publisher's Note: MDPI stays neutral with regard to jurisdictional claims in published maps and institutional affiliations.

Copyright: (C) 2022 by the authors. Licensee MDPI, Basel, Switzerland. This article is an open access article distributed under the terms and conditions of the Creative Commons Attribution (CC BY) license (https:// creativecommons.org/licenses/by/ $4.0 /)$.
The Hormel Institute, University of Minnesota, Austin, MN 55912, USA; aabhi.mn@gmail.com (A.C.); khan0672@umn.edu (I.K.); jmonts33@gmail.com (J.M.)

* Correspondence: faziz@umn.edu

† miR-223 as an emerging cancer biomarker.

Simple Summary: MicroRNAs (miRNAs) are endogenous small non-coding RNAs that function in the regulation of gene expression and regulate a wide array of biological processes, including carcinogenesis. Several mechanisms are involved in miRNA-associated cancer development, such as amplification or deletion of miRNA genes, abnormal transcriptional control of miRNAs, dysregulated epigenetic changes, and defects in miRNA biogenesis machinery. MiRNA-223 has been found to be a critical miRNA that is involved in a wide range of molecular processes. It is involved in the regulation of inflammatory cytokines, epithelial homeostasis, immune checkpoint signaling pathways, apoptosis, cell cycle, cell proliferation, invasion, and chemosensitivity. Published literature has demonstrated that miRNA-223 expression is associated with cancer development and prevention. Mir-223 functions as either a tumor suppressor or oncogene under certain circumstances, containing multiple targets or specific targets. Hence, miR-223 could be a potential candidate diagnostic biomarker, prognostic biomarker, or therapeutic target of cancer.

Abstract: In 1993, the discovery of microRNAs in Caenorhabditis elegans (C. elegans) altered the paradigmatic view of RNA biology and post-transcriptional gene regulation. Further study revealed the role of microRNAs in disease development and progression. In particular, this review highlights microRNA-223 (miR-223 or miRNA-223) expression in malignant neoplastic disorders. miR-223 expression controls aspects of hematopoiesis and apoptosis, and cell proliferation, migration, and invasion. miR-223 regulates a number of gene targets, including cytoplasmic activation/proliferation-associated protein-1 (Caprin-1), insulin-like growth factor-1 receptor (IGF$1 \mathrm{R})$, and other cell proliferation- and cell cycle-associated genes. Several studies have proposed miR-223 as a novel biomarker for early cancer diagnosis. Here, we emphasize miR-223's role in the development and progression of cancer.

Keywords: biomarker; carcinogenesis; cell proliferation; circulating miRNA; diagnosis; miR-223

\section{MicroRNAs (miRNAs)}

MicroRNAs are short ( 19-24 nucleotides in length), endogenous, non-coding RNAs that regulate protein expression by binding at complementary $3^{\prime}$-untranslated regions (UTRs) of targeted messenger RNA (mRNA) [1-4]. Binding within UTRs exerts posttranscriptional regulation of gene expression; these regulatory UTRs can affect polyadenylation, translation efficacy, and mRNA stability. miRNA association to mRNA interferes with translation by disrupting interactions between mRNAs and a number of translational factors. As a result, standard post-transcriptional gene expression is prevented or disrupted [5,6]. miRNA binding also triggers recruitment of mRNA decay factors, and their association results in decreased gene expression due to mRNA destabilization and degradation. In sum, microRNA downregulates gene expression of targeted mRNAs by inhibiting translation or by triggering transcript degradation [7-9]. 
miRNA biogenesis precedes the regulatory role of miRNA. First, primary microRNAs (pri-miRNAs) are transcribed by RNA polymerase II. Similar to most Pol II transcripts, they receive $5^{\prime}$-caps and $3^{\prime}$-polyadenlyated tails. In the nucleus, pri-miRNAs are processed into miRNA precursors (pre-miRNAs) by DiGeorge syndrome critical region gene 8 (DGCR8) and nuclear RNase III enzyme Drosha. This processing step generates the $5^{\prime}$-phosphate and 2-nucleotide $3^{\prime}$-overhang that are characteristic of pre-miRNAs. These miRNA precursors are transported into the cytoplasm by exportin-5. In the cytoplasm, Dicer1-TARBP2 complex produces mature miRNA duplex (18-25 nucleotides). The duplexed miRNAs are separated into guide and passenger strands based on their $5^{\prime}$-end base pairing. Typically, the miRNA strand with the least stable base pairing serves as the guide strand while the more stable passenger strand is usually degraded. Next, the guide strand, along with RNA-binding proteins, associates with Argonaute (AGO) proteins, forming a microribonuclear protein complex called RNA-induced silencing complex (RISC). The guide strand directs this complex to its mRNA target through sequence complementarity $[7,10]$. As mentioned previously, miRNA binding within complementary $3^{\prime}$-untranslated regions of mRNA leads to gene silencing via destabilization, degradation, and translational repression of mRNA $[1,6,7,11]$.

\section{General microRNA-223 Biology}

As a hematopoietic-specific miRNA, microRNA-223 (miR-223 or miRNA-223) is essential for myeloid lineage development and function [6,12,13]. miR-223 acts during lineage commitment, promoting granulocytic differentiation and suppressing erythrocytic differentiation of progenitor cells [14]. Using transcriptome data, Fukao et al. proposed that miR-223 transcription is driven by myeloid transcription factors, PU.1 and C/EBPs [14]. miR-223 expression in myeloid lineage cells is well characterized in both humans and mice [15]. miRNA-223 is highly conserved in various organisms, underscoring its critical role in important physiological events [14]. miR-223 is associated with hematopoiesis, immune response, and different types of cancer development $[16,17]$.

\section{3. $\mathrm{miR}-223$ and Cancer}

miR-223 is typically repressed in hepatocellular carcinoma and leukemia [18,19], although higher expression levels of miR-223 are linked to colorectal [20] and recurrent ovarian cancers [21]. In some cases, miR-223 downregulation correlates with high tumor burden, disease aggressiveness, and poor patient prognosis. Consequently, understanding the complex role of miR-223 is essential for cancer diagnosis and treatment.

Several miR-223 targets are associated with malignancy: insulin-like growth factor-1 receptor (IGF-1R), monocytic enhancer factor 2C, microtubule destabilizer stathmin 1, and artemin and Forkhead box protein O1A (FOXO1A) [22]. For example, stathmin 1 plays a key role in cell cycle progression, chromosome segregation, and cell survival. Stathmin 1 overexpression has been observed in malignant hematopoietic cells, and stathmin 1 inhibition reportedly reduced the proliferation of leukemia cell lines. In sum, perturbation of stathmin 1 expression highlights the role of miR-223 in malignant neoplastic diseases [23]. According to Ma et al., sister chromatid cohesion protein PDS5 homolog B (PDS5B) is a direct target of miR-223 in prostate cancer. Furthermore, overexpression of PDS5B, which acts as a tumor suppressor gene, leads to the reversal of $\mathrm{mR}$-223-mediated tumor progression in prostate cancer cells. Hence, the miR-223/PDS5B complex plays a critical role in the regulation of cell proliferation and invasion in prostate cancer cells [24]. In general, various hallmarks of cancer are induced by miRNA-223, including cell proliferation, tumorigenesis, and metastasis. In contrast, anti-miR-223 attenuates the invasiveness and proliferation of some cancers. Anti-miR-223 also stimulates apoptosis.

Consequently, miR-223 plays a significant role in cancers, such as gastric, hepatocellular, ovarian, lung, and esophageal cancers $[25,26]$. miR-223 downregulation is correlated with the development of chronic lymphocytic leukemia and primary small cell lung cancer (SCLC) $[26,27]$ while its upregulation is associated with ovarian and colorectal cancers. In 
particular, miR-223 is regarded as a possible biomarker in recurrent ovarian cancer. For future diagnostic strategies, miR-223 expression can be used to distinguish carcinomas from noncancerous lesions. microRNA-223 can also be considered a therapeutic target for cancer treatment [27] (Figure 1).

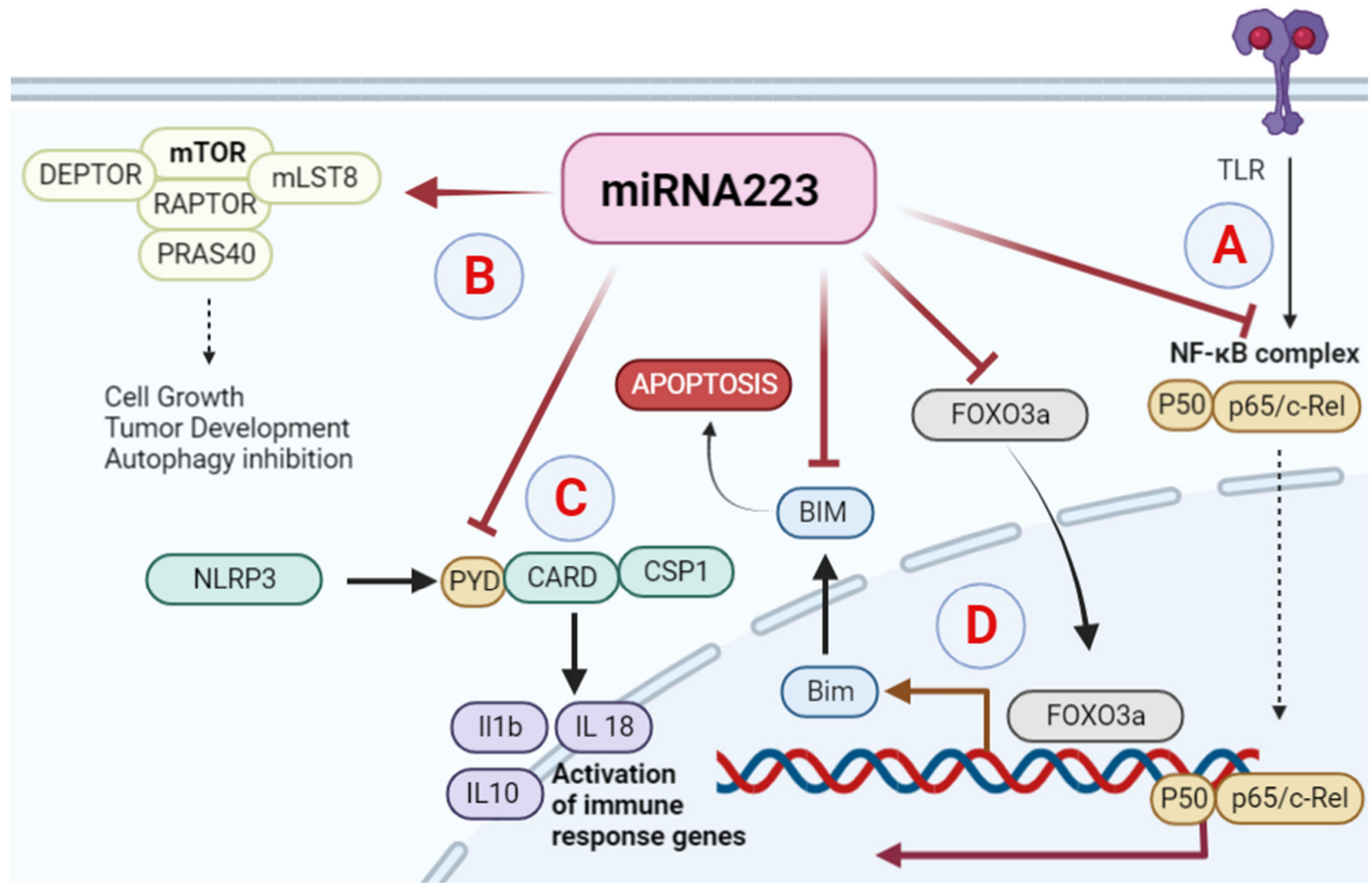

Figure 1. Role of miRNA223 in different cancers: (A) activated miR-223 negatively regulates the TLR4/MyD88-NF- $\mathrm{kB}$ signaling pathway. (B) miR-223 plays a role as a tumor suppressor in hepatocellular carcinoma by apoptosis through mTOR pathway activation. (C) miR-223 inhibits NLRP3 and its downstream factor CARD-PYD in breast cancer. (D) In colon cancer, miR-223 downregulates the transcription factor FoxO3a and BAM.

\subsection{Gastric Cancer}

Gastric cancer is a multifactorial disease with a complex interplay between genetics, lifestyle, and environment [28-31]. Helicobacter pylori infection is the most common chronic bacterial infection and affects over $50 \%$ of the world's population. It is a major cause of gastritis and gastric ulcers, and gastric cancer [32-34]. Recent gene profiling studies identified a link between miRNAs and gastric-related disease. Compared to healthy individuals, miRNA expression was significantly different in patients with chronic gastritis and gastric cancer [2]. Gastric cell lines with elevated miR-223 levels displayed a significant reduction in apoptosis. miR-223 overexpression also activated gastric cancer cell proliferation and invasion. Overall, miR-223 may play a crucial role in tumor progression and the survival of gastric cancer cells. As a result, miR-223 is proposed as an oncogene for gastric cancer [27]. As such, miR-223 expression can assist in the diagnosis and treatment of gastric cancer [27].

The mechanism responsible for increased gastric carcinogenesis was reported by Li et al., 2011. Their work demonstrated that miR-223 binds to FBXW7/hCdc4 at the $3^{\prime}-$ UTR region of FBXW7/hCdc4 mRNA. The FBXW7/hCdc4 gene is a well-established p53dependent tumor suppressor gene that encodes an ubiquitin ligase involved in chromosome stability. FBXW7 is a commonly deregulated ubiquitin-proteasome system protein in human cancers. As follows, miRNA-223 downregulation of FBXW7/hCdc4 is involved in 
gastric tumorigenesis due to increased genetic instability. In summary, miR-223 exerts its carcinogenic role by downregulating FBXW7/hCdc4 expression. This outcome rationalizes micrRNA-223 as a novel therapeutic target for gastric cancer $[2,27]$.

\subsection{Hepatocellular Carcinoma}

Hepatocellular carcinoma (HCC) is the third leading cause of cancer mortality worldwide, and the number of cases and deaths is predicted to increase [35]. HCC patients showed significantly higher miR-223 levels compared to healthy individuals. As a result, miR-223 is proposed as a potential diagnostic biomarker for HCC. However, tissue injury, more than carcinogenesis, is implicated in miR-223 overexpression for hepatocellular disorders. Hepatitis B patients with HCC-negative results showed higher serum levels of miR-223 compared to HCC and healthy subjects. Chronic hepatitis patients displayed greater hepatocyte damage compared to HCC patients, and hepatitis (tissue injury) likely leads to elevated miRNA-223 serum levels rather than HCC [36].

\subsection{Breast Cancer}

Breast cancer is a major cause of mortality among women in developed and developing countries (IARC, 2008) [37,38]. Its incidence is continuing to increase, likely due to early screening and its public health emphasis, along with other factors $[39,40]$. According to Gong et al., breast cancer cells (MDA-MB-231) express abnormally low levels of miR-223 and abnormally high levels of Caprin-1. Caprin-1 overexpression promotes proliferation and invasion of breast cancer cells. Conversely, miR-223 expression inhibits breast cancer cell proliferation and invasion in MDA-MB-231 cell lines [41]. miR-223 targets $3^{\prime}$-UTR of Caprin1 mRNA and downregulates Caprin-1 expression. A decrease in miR-223 biogenesis likely reduces Caprin-1 regulation. Caprin-1 deregulation then results in greater carcinogenesis in breast cancer cell lines, such as MDA-MB-231 [41]. In summary, miR-223 may suppress proliferation and invasion of breast cancer cells by directly targeting Caprin-1. As a result, miR-223 and Caprin-1 expression can be used predictively in cancer diagnosis and prognosis [41].

\subsection{Lung Cancer}

Lung cancer is an aggressive disease, particularly when considering its high incidence and mortality rates [42]. Consequently, novel therapeutic biomarkers are needed to improve disease outcomes [43]. Disease progression displays a negative correlation between miR-223 expression and lung cancer development and metastasis [44-46]. According to Nian et al., miR-223 functions as a potent tumor suppressor by targeting IGF-1 receptor and cyclindependent kinase 2. Low miR-223 serum levels are associated with high cancer-related death. As a result, miR-223 can be used as an early diagnostic and therapeutic biomarker to improve the treatment of lung cancer [22].

\subsection{Ovarian Cancer}

Ovarian cancer is a heterogeneous disease that encompasses a number of different cellular subtypes. The most common subtype is high-grade serous ovarian cancer (HGSOC). HGSOC is also the most lethal of all gynecologic malignancies diagnosed in the United States [47]. Recent advances have been unable to significantly improve patient outcomes. In the last 20 years, patient survival at 5 years post-diagnosis has marginally improved to $46 \%$ from about $35-38 \%$ [48].

miR-223-3p expression is upregulated in ovarian cancer. In this context, miR-223 decreases sex-determining region Y-box 11 (SOX11) expression. Inhibiting the sox11 gene negatively regulates cell proliferation, migration, and invasion. Accordingly, a therapeutic target of miR-223-3p can potentially regulate ovarian cancer by targeting SOX11 expression [48]. 


\subsection{Osteosarcoma}

Osteosarcoma is a bone tumor malignancy in adolescents and young adults [49]. miR-223 is downregulated in osteosarcoma [50,51]. Xu et al. reported that upregulation and downregulation of miRNA-223 lead to significantly diminished and enhanced cell proliferation and cell cycle progression in osteosarcoma, respectively. Thus, miR-223 is proposed as a therapeutic biomarker for osteosarcoma [51].

\subsection{Other Cancers}

miRNA dysregulation is frequently observed in colon cancer [52]. Previous studies found that the miR-223 oncogene is upregulated in colon cancer [53,54]. In 2017, Liu et al. proposed that miR-223 promotes colon cancer invasion and metastasis by downregulating p120, which reduces intercellular adhesion, promotes RhoA activity, and activates $\beta$-catenin signaling $[53,55]$. As a result, miR-223 is a potential diagnostic and therapeutic target for anti-colon cancer treatment. It was reported that miR-223 functions as an oncomiR in $\mathrm{T}$ cell acute lymphoblastic leukemia, whereas in acute myeloid leukemia (AML), it functions as a tumor suppressor [56-58]. According to Gao et al., low expression of miR-223 has been found in various human hematologic malignancies and solid tumors, where it acts as a tumor suppressor, and has a significant role in leukemia and lymphomas. miR-223 significantly inhibits the proliferation, growth rate, and colony formation of cells in vitro, and tumor formation in vivo through targeting IGF-1R and its downstream $\mathrm{PI} 3 \mathrm{~K} / \mathrm{Akt} / \mathrm{mTOR} / \mathrm{p} 70 \mathrm{~S} 6 \mathrm{~K}$ pathway in leukemia $[57,59,60]$. Compared with normal tissues, miR-223 is also upregulated within the cancerous tissues of pancreatic, gastric, and prostate cancer biopsies [55,61]. In a study by Wei et al., miR-223 promoted prostate tumor development and malignancy by decreasing cell apoptosis and increasing cell migration. These effects were reversed by upregulating SEPT6. As a gene target of miR-223, SEPT6 is downregulated by miR-223 overexpression. Consequently, SEPT6 can serve as a potential therapeutic target for prostate cancer [62].

\section{4. miR-223 and Key Motifs of Malignancy}

Many studies have reported abnormal microRNA-223 expression in different types of cancers. These studies highlight the importance of miR-223 in key motifs of malignancy: aberrant cell proliferation, invasion, and metastasis $[63,64]$.

\subsection{Proliferation and Cell Cycle Progression Are Affected by miR-223}

Several studies have investigated the role and mechanism of miRNAs in cancer cell proliferation and apoptosis $[65,66]$. miRNAs typically regulate genes that are involved in cell growth, proliferation, and apoptosis rates. According to Guz et al., genes responsible for cell cycle progression and differentiation are often downregulated in cancer cells while other regulatory genes involved in cell cycle progression and resistance to apoptosis are overexpressed [67]. According to $\mathrm{Xu}$ et al., overexpression of miR-223 leads to reduced FBXW7 mRNA levels and increases endogenous cyclin E protein, which in turn increases genomic instability. In contrast, a low level of miR-223 level leads to increased Fbw7 expression and decreased cyclin E activity. Furthermore, it was proved that miR-223 expression is reactive to acute alterations in cyclin E regulation by the Fbe7 pathway [68]. Recent evidence demonstrated that aberrant miRNA expression is critical in this malignant phenotype [69,70]. In particular, miR-223 was a key feature in cancer cell proliferation [69-71].

1. Effect of miR-223 on FOXO1 and cell proliferation

Forkhead box O (FOXO) transcription factors FOXO1, FOXO3a, FOXO4, and FOXO6 are proteins that regulate genes involved in apoptosis, DNA damage repair, cell cycle progression, and more. Ultimately, these FOXOs promote or repress multiple gene targets that are involved in tumor suppression. These targets include Bim, Trail, and Fas L, which induce apoptosis; p21, p27, and cyclin D1, which regulate cell cycle progression; and GADD45a, which supports DNA damage repair [64]. 
According to $\mathrm{Wu}$ et al., miR-223 regulates FOXO1 and its phosphorylation state [64]. Low miR-223 levels are observed in HuH7 and HCT116 colorectal cancer cell lines. Upon miR-223 overexpression, cytosolic levels of FOXO1 mRNA and protein were significantly downregulated. More specifically, the inactive form of phosphorylated FOXO1 was downregulated after miR-223 overexpression, and the active unphosphorylated form of FOXO1 was upregulated. As unphosphorylated active FOXO1 accumulated, the protein became increasingly localized in the nucleus. Nuclear FOXO1 activation increased p21 expression and cell cycle arrest [64]. Wu et al. demonstrated that miR-223 regulates FOXO1 and its downstream targets: p21, p27, and cyclin D1. Increased p21 and p27 expression, or decreased cyclin D1 expression, consistently coincided with cell growth retardation upon miR-223 overexpression. In HuH7 and HCT116 cell lines, proliferation was significantly slowed as well. As a result, $\mathrm{Wu}$ et al. established a role for miR-223 in the inhibition of cancer cell proliferation via FOXO1 regulation [64].

2. Regulation of IGF-1R by miR-223 to modulate cell proliferation

Insulin-like growth factor-1 receptor (IGF-1R) and its ligands regulate cell proliferation and apoptosis. IGF-1R deregulation has been widely documented in the progression of human malignancies [72,73]. According to Jia et al., miR-223 expression inhibits hepatoma cell proliferation, growth rate, and colony formation by targeting IGF-1R for downregulation. The downstream pathway, Akt/mTOR/p70S6K, is inhibited as well. In sum, IGF-1R is a functional target for miR-223-directed suppression of cell proliferation [74].

\section{Role of miR-223 on E2F1 and cell proliferation}

The E2F family of transcription factors regulate cell cycle progression by transactivating cell proliferation genes [75]. In particular, E2F1 overexpression leads to enhanced proliferation of cancer cells [75,76]. According to Pulikkan et al., miR-223 and E2F1 transcription factor act within an autoregulatory negative feedback loop in acute myeloid leukemia (AML). In brief, E2F1 induces $\mathrm{C} / \mathrm{EBP} \alpha$ expression, which subsequently induces miR-223. In turn, miR-223 represses E2F1 expression. However, AML exhibits low miR-223 expression, and E2F1 is responsible for this phenotype. E2F1 binds to the miR-223 promoter in AML blast cells. This association is responsible for transcriptional repression of the miR-223 gene and the low miR-223 expression observed in AML [75,76]. Upregulation of miR-223 would reverse the effects of E2F1 overexpression and suppress cell proliferation in AML [76].

4. Effect of miR-223 in cytoplasmic activation/proliferation-associated protein-1 (Caprin1)-induced cell proliferation

Cytoplasmic activation/proliferation-associated protein-1 (Caprin-1) is associated with cell proliferation. Caprin-1 downregulation leads to reduced cell proliferation and a prolonged cell cycle phase (G1 phase) $[77,78]$. According to Gong et al., miR-223 interacts with Caprin-1, and this interplay may be associated with the phenotypic proliferation and migration patterns observed in breast cancer cells with low miR-223 levels. Overall, miR-223 overexpression leads to decreased Caprin-1 expression, which in turn represses the proliferation and invasion of breast cancer cells [41].

\subsection{Metastasis and Invasion of Cancer}

Several studies reported the role of miR-223 in tumor migration and invasion, and miR-223 is considered a metastasis-promoting miRNA. For example, miR-223 regulates certain transcription factors to promote gastric cancer cell migration and invasion in vivo and in vitro. According to Li et al., miR-223 overexpression facilitates gastric cancer progression to invasive and metastatic stages. In contrast, its silencing leads to inhibited gastric cancer cell migration and invasion [2]. Haneklaus et al. also concluded that miR-223 overexpression may promote a shift to metastasis [5].

$\mathrm{Li}$ et al. investigated the regulatory role of miR-223 in esophageal cancer cell migration and invasion. They found that esophageal cancer cells display low miR-223 and 
high artemin levels. Subsequent miR-223 overexpression inhibited artemin levels and suppressed cell migration and invasion [79].

\section{5. miR-223 as a Circulating Noninvasive Biomarker}

miRNAs can serve as effective biomarkers for cancer diagnosis $[36,80]$. Tissue miRNA expression profiles can be used as diagnostic and therapeutic biomarkers for cancer [81]; however, their relative inaccessibility and invasiveness make tissue miRNA levels less suitable for diagnostic testing compared to freely circulating miRNA in plasma or serum. The greatest advantage of circulating miRNAs is their capacity to be non-invasively sampled via blood collection. Circulating miRNA detection could also provide greater sensitivity and specificity compared to current serum biomarkers, such as CA19-9 and CEA [82,83]. Consequently, circulating miRNAs are promising early diagnostic tools. According to Chang et al., miR-233 found in both clinical samples in plasma and stool significantly diagnoses colorectal cancer patients. Furthermore, stool and plasma clinical samples yield the highest sensitivity (96.8\%) and specificity (75\%), with an accuracy of 0.907 [84]. According to Li et al., miR-223 levels are significantly higher in gastric cancer plasma samples. As a result, microRNA-223 can serve as a biomarker for gastric cancer. Several other types of cancer show high miR-223 expression as well, including esophageal and hepatocellular carcinomas. In summary, circulating miR-223 can potentially serve as a novel noninvasive biomarker in cancer diagnosis [80] (Table 1).

Table 1. The roles of MiR223 in the regulation of carcinogenesis by targeting specific targets.

\begin{tabular}{|c|c|c|c|c|}
\hline Clinical Relevance & $\begin{array}{l}\text { Molecular Mechanism } \\
\text { Involved or Function }\end{array}$ & Experimental Model & Specific Targets & References \\
\hline Breast cancer & $\begin{array}{l}\text { miR-233-3p mimics inhibited the } \\
\text { NLRP3-dependent processes in } \\
\text { cancer cells by suppressing the } \\
\text { NLRP3 and downstream factors, } \\
\text { including PYD and CARD } \\
\text { domain-containing protein, } \\
\text { IL-1 } \beta \text {, and IL-18. }\end{array}$ & $\begin{array}{c}\text { Breast cell lines: HMEC, } \\
\text { MDA-MB231, MCF-7, and } \\
\text { SKBR3 } \\
\text { Xenograft mouse model }\end{array}$ & $\begin{array}{l}\text { NLRP3, PYD, CARD, } \\
\text { IL1 } \beta, \text { IL18 }\end{array}$ & PMID: 30747211 \\
\hline $\begin{array}{l}\text { Hepatocellular carcinoma } \\
\text { (HCC) }\end{array}$ & $\begin{array}{c}\text { Checkpoint kinase } 1, \text { DNA } \\
\text { methyltransferase } 1 \text {, baculoviral } \\
\text { IAP repeat-containing } 5 \text {, kinesin } \\
\text { family member } 23 \text {, and collagen, } \\
\text { type I, } \alpha 1 \text { target genes were } \\
\text { considered the hub genes of } \\
\text { miR-223-3p in HCC, which are } \\
\text { significantly upregulated in } \\
\text { HCC }\end{array}$ & $\begin{array}{l}\text { Database: GEO database, } \\
\text { TCGA database, } \\
\text { Meta-analysis., } \\
\text { Bioinformatics evaluation, } \\
\text { Protein-protein } \\
\text { interaction (PPI) network } \\
\text { construction }\end{array}$ & $\begin{array}{l}\text { Checkpoint kinase } 1, \text { DNA } \\
\text { methyltransferase } 1, \\
\text { baculoviral IAP } \\
\text { repeat-containing } 5 \text {, } \\
\text { kinesin family member } 23, \\
\text { and collagen, type I, } \alpha 1 \text {. }\end{array}$ & PMID: 29207133 \\
\hline Prostate Cancer & $\begin{array}{l}\text { miR-223 inhibited the malignant } \\
\text { behavior of prostate cancer cells } \\
\text { while EYA3/c-Myc had the } \\
\text { opposite effect. Moreover, } \\
\text { circGNG4 enhanced the } \\
\text { expression of EYA3/c-Myc by } \\
\text { sponging miR-223 to promote } \\
\text { the growth of prostate cancer } \\
\text { tumors in vivo. }\end{array}$ & $\begin{array}{l}\text { Prostate clinical samples: } \\
\text { Prostate Cancer and } \\
\text { adjacent normal tissues. } \\
\text { Prostate cell lines: PC-3, } \\
\text { LNCaP, VCaP, and } \\
\text { DUL145, and the human } \\
\text { normal prostatic epithelial } \\
\text { cell line, RWPE-1 } \\
\text { Xenograft mouse model }\end{array}$ & $\begin{array}{c}\text { circGNG4, EYA } \\
\text { transcriptional coactivator, } \\
\text { phosphatase } 3 \\
\text { (EYA3)/c-Myc }\end{array}$ & PMID: 34395419 \\
\hline $\begin{array}{l}\text { Esophageal squamous cell } \\
\text { carcinoma (ESCC) }\end{array}$ & $\begin{array}{l}\text { High expression level of miR-223 } \\
\text { had a significant adverse impact } \\
\text { on the survival of ESCC patients } \\
\text { through repression of the } \\
\text { function of FBXW7. }\end{array}$ & $\begin{array}{c}\text { ESCC clinical samples: } \\
\text { ESCC Primary ESCC } \\
\text { tissue samples and human } \\
\text { ESCC cell lines: TE1, TE4, } \\
\text { TE6, TE8, TE9, TE10, TE14, } \\
\text { and TE15. }\end{array}$ & FBXW7 & PMID: 22108521 \\
\hline
\end{tabular}


Table 1. Cont.

\begin{tabular}{|c|c|c|c|c|}
\hline Clinical Relevance & $\begin{array}{l}\text { Molecular Mechanism } \\
\text { Involved or Function }\end{array}$ & Experimental Model & Specific Targets & References \\
\hline Gastric cancer & $\begin{array}{l}\text { miR-223 induced by the } \\
\text { transcription factor Twist, } \\
\text { post-transcriptionally } \\
\text { downregulates EPB41L3 } \\
\text { expression by directly targeting } \\
\text { its } 3^{\prime} \text {-untranslated regions. }\end{array}$ & $\begin{array}{c}\text { Gastric clinical samples: } \\
\text { Gastric cancer and normal } \\
\text { gastric tissues, } \\
\text { Gastric cell lines: } \\
\text { HEK293 cell, GPG29 cell, } \\
\text { immortalized normal } \\
\text { gastric mucosa GES cell, } \\
\text { normal stomach } \\
\text { fibroblastic cell NSFC, } \\
\text { non-metastatic gastric } \\
\text { cancer SUN-1, KATO-III, } \\
\text { NUGC-3 cells, and } \\
\text { metastatic gastric cancer } \\
\text { XGC-9811L, AGS, and } \\
\text { N87. }\end{array}$ & EPB41L3 & PMID: 21628394 \\
\hline $\begin{array}{l}\text { Hepatocellular carcinoma } \\
\text { (HCC) }\end{array}$ & $\begin{array}{l}\text { miR-223 functions as a tumor } \\
\text { suppressor and plays a critical } \\
\text { role in inhibiting the } \\
\text { tumorigenesis and promoting } \\
\text { the apoptosis of HCC through } \\
\text { the mTOR signaling pathway by } \\
\text { targeting Rab1. }\end{array}$ & $\begin{array}{l}\text { Hepatocellular cell lines: } \\
\text { Huh7, Hep3B, Bel-7402, } \\
\text { and the HepG2 cell lines }\end{array}$ & Rab1, mTOR & PMID: 27998765 \\
\hline Lung cancer & $\begin{array}{l}\text { miR-223 targets IGF-1R, a } \\
\text { transmembrane receptor } \\
\text { tyrosine kinase related to lung } \\
\text { cancer oncogenesis, tumor } \\
\text { growth, and cancer cell survival. } \\
\text { miR-223 overexpression leads to } \\
\text { tumor suppression in lung } \\
\text { cancer }\end{array}$ & & IGF-1R, & PMID: 10857553 \\
\hline Liver cancer & $\begin{array}{l}\text { miR-223-3p down-regulated the } \\
\text { expression of FAT1, and } \\
\text { inhibited the proliferation, } \\
\text { migration, invasion, and EMT of } \\
\text { liver cancer cells by targeting } \\
\text { FAT1. FAT1 was highly } \\
\text { expressed in liver cancer tissues } \\
\text { and cells while miR-223-3p was } \\
\text { lowly expressed. }\end{array}$ & $\begin{array}{c}\text { Liver clinical samples: } \\
\text { Liver Tumor tissues and } \\
\text { corresponding adjacent } \\
\text { tissues. } \\
\text { Liver cell lines: Normal } \\
\text { human hepatocyte, L-02 } \\
\text { and human liver cancer } \\
\text { cell lines, Hep G2, } \\
\text { SMMC-7721, Hep 3b, and } \\
\text { Li-7, } \\
\end{array}$ & FAT1 & PMID: 32233593 \\
\hline Brain cancer & $\begin{array}{l}\text { miR-223-3p could be decreased } \\
\text { by NLRP3 overexpression, } \\
\text { which was considered as one of } \\
\text { target genes of miR-223-3p. } \\
\text { miR-223-3p might act as a } \\
\text { suppressor and a potential } \\
\text { therapy target of glioblastoma. }\end{array}$ & & NLRP3 & PMID: 30033329 \\
\hline Colon cancer & $\begin{array}{c}\text { miR-223 regulate the } \\
\text { FoxO3a/BIM signaling pathway } \\
\text { and colorectal cancer cell } \\
\text { proliferation and apoptosis. } \\
\text { Downregulating the expression } \\
\text { of miR-223 increased the } \\
\text { expression of FoxO3a and BIM } \\
\text { and weakened cell proliferation } \\
\text { and induced apoptosis. }\end{array}$ & $\begin{array}{l}\text { Colon cell lines: NCM460 } \\
\text { and SW620 cancer cells. }\end{array}$ & FoxO3 & PMID: 29949152 \\
\hline
\end{tabular}

\section{6. miR-223 Application as a Diagnostic and Therapeutic Biomarker for Cancers}

Cancer treatment is challenging for many reasons, including clinical and tumor heterogeneity and the lack of disease-specific diagnostic biomarkers [85-88]. Certain microRNAs have tumor suppressor or pro-oncogenic functions, making them attractive targets for cancer therapy [74]. Significant advances have been made in miRNA-based therapy; however, many challenges must be overcome before clinical usage [89]. Regardless, several studies reported miR-223 expression as a potential diagnostic and therapeutic target [36,89-91]. 


\subsection{Hepatocellular Carcinoma and Liver Damage}

Hepatocellular carcinoma (HCC) displays a high recurrence rate. This common reoccurrence requires further investigation into diagnostic and therapeutic targets for HCC treatment [92]. miR-223 overexpression was reported in patients with either HCC or chronic hepatitis B. The usefulness of miR-223 as a diagnostic biomarker for HCC is limited by its shared miR-223 profile. Chronic hepatitis B also displays elevated miR-223 levels; however, this overexpression is caused by inflammation and liver injury, not the presence of hepatocellular carcinoma [36,93,94].

According to Karakatsanis et al., miR-223 downregulation inhibits HCC cell growth, suggesting that miR-223 plays an important role in HCC progression and metastasis [94] Moreover, it was reported that miR-223-3p could be used as a promising prognostic biomarker as circulating miR-223-3p significantly differentiates HCC from the non-HCC groups [95]. Consequently, further investigation of miR-223 is essential.

\subsection{Breast Cancer}

Escobar et al. highlighted the effects of macrophages and miRNA on breast cancer cells. miR-223 overexpression, coupled with high levels of macrophage infiltration, results in an aggressive cancer phenotype [91]. In 2018, Yang et al. showed that miR-223 inhibits the proliferation and invasion of breast cancer by targeting STIM1 [96]. According to Chen et al., high expression of miR-223 acts as a tumor suppressor, which is correlated with prolonged survival in triple-negative breast cancer patients. Hence, miR-223 could be an independent prognostic biomarker in breast cancer [97]. As reported, miR-223 can serve as a potential diagnostic biomarker for breast cancer [91,96].

\subsection{Esophageal Cancer}

Esophageal cancer is a leading cause of cancer-related deaths worldwide. Most physicians recommend surgical resection for esophageal carcinomas at their early stages [98]. Due to the limited treatment options, further research is needed to identify biomolecular pathways involved in esophageal cancer malignancy $[90,98,99]$.

Artemin (ARTN) is a growth factor associated with the tumorigenesis and progression of human cancers. ARTN also promotes cell migration, invasion, and metastasis [99-101]. After chemotherapy, artemin expression is strongly correlated with relapse and death in carcinoma patients [102,103].

According to $\mathrm{Wu}$ et al., miR-223 directly binds the ARTN 3'-UTR and regulates ARTN protein expression [102]. ARTN function is suppressed by miR-223 overexpression, which reduces esophageal cancer cell migration and invasion. In contrast, ARTN upregulation via miR-223 silencing promotes cell migration and invasion [102]. These observations rationalize microRNA-223 and artemin as therapeutic targets for esophageal cancer treatment.

\subsection{Lung Cancer}

In lung cancer, like all cancers, early diagnosis promotes favorable patient outcomes [103]. As a result, the identification of novel early diagnostic biomarkers related to tumorigenesis is vital for future advancements in cancer diagnosis and treatment [43].

miR-223 targets IGF-1R, a transmembrane receptor tyrosine kinase related to lung cancer oncogenesis, tumor growth, and cancer cell survival [103]. IGF-1R upregulation is involved in the initial dysregulation that shifts previously healthy cells towards tumorigenesis and malignancy. In contrast, IGF-1R downregulation sensitizes lung cancer cells to chemotherapy and radiation by inhibiting cell proliferation. As reported, miR-223 overexpression leads to tumor suppression in lung cancer [103]. According to Antona et al., miR-223 could be an early-stage serum biomarker for non-small cell lung cancer (NSCLC). Moreover, miR-223 is considered as an effective and reproducible serum biomarker [104]. Overall, miR-223 targets IGF-1R and its downstream signaling pathway for downregulation, leading to inhibited cell growth and proliferation [74]. Targeting miR-223 for overexpression could be a good strategy for lung cancer treatment. 


\section{Concluding Remarks}

This review highlights the importance of miR-223 in cancer biology. miR-223 expression potentially plays a major role in cancer diagnosis, progression, and treatment. Data reported within this review characterizes miR-223 as emerging triple-negative breast, gastric, lung, and ovarian cancer biomarkers. Several genes and gene products were identified as targets of miR-223, including NLRP3, IL18, IL1 $\beta$, DNA methyltransferase 1 , and checkpoint kinase-1, signifying its potential use as a cancer-specific diagnostic biomarker and therapy. However, further investigation is needed to better understand the mechanisms of miR-223 involved in tumor activation or suppression. Nonetheless, miR-223 regulation is a promising tool for controlling key cancer motifs: increased cell growth, proliferation, and invasiveness in addition to decreased apoptosis rates.

Author Contributions: All authors were contributed significantly. F.A., conceptualization, writingoriginal draft preparation, writing - review and supervision of the manuscript. F.A., A.C. and I.K., collected the references, F.A., Figures and tables. F.A and J.M., edited the manuscript. All authors have read and agreed to the published version of the manuscript.

Funding: Not applicable.

Institutional Review Board Statement: Not applicable.

Informed Consent Statement: Not applicable.

Data Availability Statement: Not applicable.

Conflicts of Interest: The authors declare that they have no conflict of interests.

\begin{tabular}{ll}
\multicolumn{2}{l}{ Abbreviations } \\
AGO & Argonaute \\
ARTN & Artemin \\
Caprin-1 & cytoplasmic activation/proliferation-associated protein-1 \\
DGCR8 & DiGeorge syndrome critical region gene 8 \\
FOXO & Forkhead box protein O \\
HCC & Hepatocellular carcinoma \\
HGSOC & high-grade serous ovarian cancer \\
IGF-1R & Insulin-like growth factor 1 receptor \\
IARC & International agency for research on cancer \\
miRNAs & microRNAs \\
mRNA & messenger RNA \\
miR-223 & microRNA-223 \\
MDSCs & Myeloid-derived suppressor cells \\
pre-miRNAs & miRNA precursors \\
RISC & RNA-induced silencing complex \\
SOX & sex determining region Y-box 11 \\
STM1 & Stathmin1 \\
UTR & Untranslated region
\end{tabular}

\section{References}

1. Hunter, M.P.; Ismail, N.; Zhang, X.; Aguda, B.D.; Lee, E.J; Yu, L.; Xiao, T.; Schafer, J.; Lee, M.-L.T.; Schmittgen, T.D.; et al. Detection of microRNA Expression in Human Peripheral Blood Microvesicles. PLoS ONE 2008, 3, e3694. [CrossRef]

2. Li, X.; Zhang, Y.; Zhang, H.; Liu, X.; Gong, T.; Li, M.; Sun, L.; Ji, G.; Shi, Y.; Han, Z.; et al. miRNA-223 Promotes Gastric Cancer Invasion and Metastasis by Targeting Tumor Suppressor EPB41L3. Mol. Cancer Res. 2011, 9, 824-833. [CrossRef] [PubMed]

3. Guo, L.; Chen, F. A challenge for miRNA: Multiple isomiRs in miRNAomics. Gene 2014, 544, 1-7. [CrossRef]

4. Dexheimer, P.J.; Cochella, L. MicroRNAs: From Mechanism to Organism. Front. Cell Dev. Biol. 2020, 8, 409. [CrossRef]

5. Haneklaus, M.; Gerlic, M.; O'Neill, L.A.J.; Masters, S.L. miR-223: Infection, inflammation and cancer. J. Intern. Med. 2013, 274, 215-226. [CrossRef]

6. Ge, Q.; Brichard, S.; Yi, X.; Li, Q. microRNAs as a New Mechanism Regulating Adipose Tissue Inflammation in Obesity and as a Novel Therapeutic Strategy in the Metabolic Syndrome. J. Immunol. Res. 2014, 2014, 1-10. [CrossRef] [PubMed] 
7. Finnegan, E.F.; Pasquinelli, A.E. MicroRNA biogenesis: Regulating the regulators. Crit. Rev. Biochem. Mol. Biol. 2013, 48, 51-68. [CrossRef]

8. Aziz, F.; Yulin, L.; Yan, Q. miR-1290 stimulates proliferation of gastric cancer by targeting SP1 with overexpression of fucosyltransferase IV and $\alpha 1,3$-fucosylated glycans. biorXiv 2020. [CrossRef]

9. Zheng, Q.; Cui, X.; Zhang, D.; Yang, Y.; Yan, X.; Liu, M.; Niang, B.; Aziz, F.; Liu, S.; Yan, Q.; et al. miR-200b inhibits proliferation and metastasis of breast cancer by targeting fucosyltransferase IV and $\alpha 1,3$-fucosylated glycans. Oncogenesis 2017, 6, e358. [CrossRef]

10. Winter, J.; Jung, S.; Keller, S.; Gregory, R.I.; Diederichs, S. Many roads to maturity: MicroRNA biogenesis pathways and their regulation. Nat. Cell Biol. 2009, 11, 228-234. [CrossRef]

11. Finch, M.L.; Marquardt, J.U.; Yeoh, G.C.; Callus, B.A. Regulation of microRNAs and their role in liver development, regeneration and disease. Int. J. Biochem. Cell Biol. 2014, 54, 288-303. [CrossRef]

12. Chen, C.-Z.; Li, L.; Lodish, H.F.; Bartel, D.P. MicroRNAs Modulate Hematopoietic Lineage Differentiation. Science 2004, 303, 83-86. [CrossRef] [PubMed]

13. O'Connell, R.M.; Zhao, J.L.; Rao, D. MicroRNA function in myeloid biology. Blood 2011, 118, 2960-2969. [CrossRef]

14. Fukao, T.; Fukuda-Yuzawa, Y.; Kiga, K.; Sharif, J.; Hino, K.; Enomoto, Y.; Kawamura, A.; Nakamura, K.; Takeuchi, T.; Tanabe, M. Matters Arising an Evolutionarily Conserved Mechanism for MicroRNA-223 Expression Revealed by MicroRNA Gene Profiling. Cell 2007, 129, 617-631. [CrossRef]

15. Gilicze, A.B.; Wiener, Z.; Tóth, S.; Buzás, E.; Pállinger, É.; Falcone, F.; Falus, A. Myeloid-Derived microRNAs, miR-223, miR27a, and miR-652, Are Dominant Players in Myeloid Regulation. BioMed Res. Int. 2014, 2014, 870267. [CrossRef] [PubMed]

16. Jeffries, J.; Zhou, W.; Hsu, A.; Deng, Q. miRNA-223 at the crossroads of inflammation and cancer. Cancer Lett. 2019, 451, 136-141. [CrossRef] [PubMed]

17. Yuan, S.; Wu, Q.; Wang, Z.; Che, Y.; Zheng, S.; Chen, Y.; Zhong, X.; Shi, F. miR-223: An Immune Regulator in Infectious Disorders. Front. Immunol. 2021, 12, 781815. [CrossRef]

18. Wong, Q.W.; Lung, R.W.; Law, P.T.; Lai, P.B.-S.; Chan, K.Y.Y.; To, K.; Wong, N. MicroRNA-223 Is Commonly Repressed in Hepatocellular Carcinoma and Potentiates Expression of Stathmin1. Gastroenterology 2008, 135, 257-269. [CrossRef]

19. Yendamuri, S.; Calin, G.A. The role of microRNA in human leukemia: A review. Leukemia 2009, 23, 1257-1263. [CrossRef]

20. Zhang, J.; Luo, X.; Li, H.; Yue, X.; Deng, L.; Cui, Y.; Lu, Y. MicroRNA-223 functions as an oncogene in human colorectal cancer cells. Oncol. Rep. 2014, 32, 115-120. [CrossRef]

21. Laios, A.; O’Toole, S.; Flavin, R.; Martin, C.; Kelly, L.; Ring, M.; Finn, S.P.; Barrett, C.; Loda, M.; Gleeson, N.; et al. Potential role of miR-9 and miR-223 in recurrent ovarian cancer. Mol. Cancer. 2008, 7, 35. [CrossRef] [PubMed]

22. Nian, W.; Ao, X.; Wu, Y.; Huang, Y.; Shao, J.; Wang, Y.; Chen, Z.; Chen, F.; Wang, D. miR-223 functions as a potent tumor suppressor of the Lewis lung carcinoma cell line by targeting insulin-like growth factor-1 receptor and cyclin-dependent kinase 2 . Oncol. Lett. 2013, 6, 359-366. [CrossRef] [PubMed]

23. Machado-Neto, J.A.; Teresinha, S.; Saad, O.; Traina, F. Stathmin 1 in normal and malignant hematopoiesis. BMB Rep. 2014, 47, 660-665. [CrossRef]

24. Ma, J.; Cao, T.; Cui, Y.; Zhang, F.; Shi, Y.; Xia, J.; Wang, Z.P. miR-223 Regulates Cell Proliferation and Invasion via Targeting PDS5B in Pancreatic Cancer Cells. Mol. Ther.-Nucleic Acids. 2019, 14, 583-592. [CrossRef] [PubMed]

25. Aziz, F. The emerging role of miR-223 as novel potential diagnostic and therapeutic target for inflammatory disorders. Cell. Immunol. 2016, 303, 1-6. [CrossRef]

26. Stamatopoulos, B.; Meuleman, N.; Haibe-Kains, B.; Saussoy, P.; Van Den Neste, E.; Michaux, L.; Heimann, P.; Martiat, P.; Bron, D.; Lagneaux, L. microRNA-29c and microRNA-223 down-regulation has in vivo significance in chronic lymphocytic leukemia and improves disease risk stratification. Blood 2009, 113, 5237-5245. [CrossRef]

27. Tito, C.; De Falco, E.; Rosa, P.; Iaiza, A.; Fazi, F.; Petrozza, V.; Calogero, A. Circulating microRNAs from the Molecular Mechanisms to Clinical Biomarkers: A Focus on the Clear Cell Renal Cell Carcinoma. Genes 2021, 12, 1154. [CrossRef]

28. Aziz, F.; Qiu, Y. The role of anti-LeY antibody in the downregulation of MAPKs/COX-2 pathway in gastric cancer. Curr. Drug Targets. 2014, 15, 469-476. [CrossRef]

29. Aziz, F.; Chakarobaty, A.; Liu, K.; Zhang, T.; Li, X.; Du, R.; Monts, J.; Xu, G.; Li, Y.; Bai, R.; et al. Gastric tumorigenesis induced by combining Helicobacter pylori infection and chronic alcohol through IL-10 inhibition. Carcinogenesis 2021, 114. [CrossRef]

30. Aziz, F.; Khan, I.; Shukla, S.; Dey, D.K.; Yan, Q.; Chakraborty, A.; Yoshitomi, H.; Hwang, S.-K.; Sonwal, S.; Lee, H.; et al. Partners in crime: The Lewis Y antigen and fucosyltransferase IV in Helicobacter pylori-induced gastric cancer. Pharmacol. Ther. 2021, 107994. [CrossRef]

31. Aziz, F.; Xin, M.; Gao, Y.; Chakroborty, A.; Khan, I.; Monts, J.; Monson, K.; Bode, A.M.; Dong, Z. Induction and Prevention of Gastric Cancer with Combined Helicobacter pylori and Capsaicin Administration and DFMO Treatment, Respectively. Cancers 2020, 12, 816. [CrossRef] [PubMed]

32. Aziz, F.; Sherwani, S.K.; Akhtar, S.S.; Kazmi, S.U. Development of an in-house enzyme-linked immunosorbent assay based on surface whole cell antigen for diagnosis of Helicobacter pylori infection in patients with gastroduodenal ulcer disease. World $J$. Microbiol. Biotechnol. 2014, 30, 305-315. [CrossRef] [PubMed]

33. Aziz, F.; Yang, X.; Wen, Q.; Yan, Q. A method for establishing human primary gastric epithelial cell culture from fresh surgical gastric tissues. Mol. Med. Rep. 2015, 12, 2939-2944. [CrossRef] [PubMed] 
34. Aziz, F.; Taj, Y.; Kazmi, S.U. Development of an In-House Enzyme-Linked Immunosorbent Assay Based on Helicobacter pylori Sonicate Whole Cell Antigen for Diagnosis of Gastroduodenal Ulcer Disease in Karachi, Pakistan. Int. J. Microbiol. Adv. Immunol. 2013, 24-31. [CrossRef]

35. Parkin, D.M.; Bray, F.; Ferlay, J.; Pisani, P. Global Cancer Statistics, 2002. CA Cancer J. Clin. 2005, 55, 74-108. [CrossRef]

36. Qi, P.; Cheng, S.; Wang, H.; Li, N.; Chen, Y.; Gao, C. Serum MicroRNAs as Biomarkers for Hepatocellular Carcinoma in Chinese Patients with Chronic Hepatitis B Virus Infection. PLoS ONE 2011, 6, 6-13. [CrossRef]

37. Zhou, Q.; Shen, J.; Liu, Y.; Lin, G.; Dong, H.; Li, K. Effects of Doctor-patient Communication on Quality of Life among Breast Cancer Patients in Southern China. Asian Pac. J. Cancer Prev. 2014, 15, 5639-5644. [CrossRef]

38. Morse, E.P.; Maegga, B.; Joseph, G.; Miesfeldt, S. Breast Cancer Knowledge, Beliefs, and Screening Practices among Women Seeking Care at District Hospitals in Dar es Salaam, Tanzania. Breast Cancer. 2014, 8, 73-79. [CrossRef]

39. Lahart, I.M.; Metsios, G.S.; Nevill, A.M.; Carmichael, A.R. Physical Activity Levels in Women Attending Breast Screening, Receiving Chemotherapy and Post-Breast Cancer Treatment; A Cross-Sectional Study. Int. J. Environ. Res. Public Health. 2014, 11, 5487-5496. [CrossRef]

40. Yan, X.; Lin, Y.; Liu, S.; Aziz, F.; Yan, Q. Fucosyltransferase IV (FUT4) as an effective biomarker for the diagnosis of breast cancer. Biomed. Pharmacother. 2015, 70, 299-304. [CrossRef]

41. Gong, B.; Hu, H.; Chen, J.; Cao, S.; Yu, J.; Xue, J.; Chen, F.; Cai, Y.; He, H.; Zhang, L. Caprin-1 is a novel microRNA-223 target for regulating the proliferation and invasion of human breast cancer cells. Biomed. Pharmacother. 2013, 67, 629-636. [CrossRef] [PubMed]

42. Rezola, A.; Pey, J.; Rubio, A.; Planes, F.J. In-Silico Prediction of Key Metabolic Differences between Two Non-Small Cell Lung Cancer Subtypes. PLoS ONE 2014, 9, e103998. [CrossRef] [PubMed]

43. Martini, S.D.L.; Müller, C.B.; Meurer, R.T.; Cruz, M.; Mariano, R.; E Silva, M.B.; Klamt, F.; Andrade, C.F. The potential role of extracellular regulatory kinase in the survival of patients with early stage adenocarcinoma. J. Thorac. Dis. 2014, 6, 930-936 [CrossRef]

44. Shi, J.; Jiang, X.; Yu, Z.; He, G.; Ning, H.; Wu, Z.; Cai, Y.; Yu, H.; Chen, A. ZNRF3 contributes to the growth of lung carcinoma via inhibiting Wnt/ $\beta$-catenin pathway and is regulated by miR-93. Tumor Biol. 2015, 37, 3051-3057. [CrossRef]

45. Chen, Z.; Wu, Y.; Meng, Q.; Xia, Z. Elevated microRNA-25 inhibits cell apoptosis in lung cancer by targeting RGS3. In Vitro Cell. Dev. Biol. Anim. 2016, 52, 62-67. [CrossRef]

46. Dong, W.; Yao, C.; Teng, X.; Chai, J.; Yang, X.; Li, B. MiR-140-3p suppressed cell growth and invasion by downregulating the expression of ATP8A1 in non-small cell lung cancer. Tumor Biol. 2015, 37, 2973-2985. [CrossRef]

47. Siegel, R.L.; Miller, K.D.; Jemal, A. Cancer statistics, 2012. CA Cancer J. Clin. 2016, 66, 7-30. [CrossRef]

48. Fang, G.; Liu, J.; Wang, Q.; Huang, X.; Yang, R.; Pang, Y.; Yang, M. MicroRNA-223-3p Regulates Ovarian Cancer Cell Proliferation and Invasion by Targeting SOX11 Expression. Int. J. Mol. Sci. 2017, 18, 1208. [CrossRef]

49. Jemal, A.; Center, M.M.; DeSantis, C.; Ward, E.M. Global Patterns of Cancer Incidence and Mortality Rates and Trends. Cancer Epidemiol Biomarkers Prev. 2010, 19, 1893-1908. [CrossRef]

50. Ji, Q.; Xu, X.; Song, Q.; Xu, Y.; Tai, Y.; Goodman, S.B.; Bi, W.; Xu, M.; Jiao, S.; Maloney, W.J.; et al. miR-223-3p Inhibits Human Osteosarcoma Metastasis and Progression by Directly Targeting $\mathrm{CDH}_{6}$. Mol. Ther. 2018, 26, 1299-1312. [CrossRef]

51. Xu, J.; Yao, Q.; Hou, Y.; Xu, M.; Liu, S.; Yang, L.; Zhang, L.; Xu, H. MiR-223/Ect2/p21 signaling regulates osteosarcoma cell cycle progression and proliferation. Biomed. Pharmacother. 2019, 67, 381-386. [CrossRef] [PubMed]

52. Wu, W.K.; Law, P.T.; Lee, C.W.; Cho, C.H.; Fan, D.; Wu, K.; Yu, J.; Sung, J.J. MicroRNA in colorectal cancer: From benchtop to bedside. Carcinogenesis 2010, 32, 247-253. [CrossRef] [PubMed]

53. Liu, L.; Zhang, C.; Li, X.; Sun, W.; Qin, S.; Qin, L.; Wang, X. miR-223 promotes colon cancer by directly targeting p120 catenin. Oncotarget 2017, 8, 63764-63779. [CrossRef]

54. Chai, B.; Guo, Y.; Cui, X.; Liu, J.; Suo, Y.; Dou, Z.; Li, N. MiR-223-3p promotes the proliferation, invasion and migration of colon cancer cells by negative regulating PRDM1. Am. J. Transl. Res. 2019, 11, 4516-4523.

55. Bloomston, M.; Frankel, W.L.; Petrocca, F.; Volinia, S.; Alder, H.; Hagan, J.P.; Liu, C.-G.; Bhatt, D.; Taccioli, C.; Croce, C.M. MicroRNA Expression Patterns to Differentiate Pancreatic Adenocarcinoma from Normal Pancreas and Chronic Pancreatitis. JAMA 2019, 297, 1901-1908. [CrossRef] [PubMed]

56. Fazi, F.; Racanicchi, S.; Zardo, G.; Starnes, L.; Mancini, M.; Travaglini, L.; Diverio, D.; Ammatuna, E.; Cimino, G.; Lo-Coco, F.; et al. Epigenetic Silencing of the Myelopoiesis Regulator microRNA-223 by the AML1/ETO Oncoprotein. Cancer Cell. 2007, 12, 457-466. [CrossRef]

57. Gao, Y.; Lin, L.; Li, T.; Yang, J.; Wei, Y. The role of miRNA-223 in cancer: Function, diagnosis and therapy. Gene 2017, 616, 1-7. [CrossRef]

58. Mavrakis, K.J.; Van Der Meulen, J.; Wolfe, A.L.; Liu, X.; Mets, E.; Taghon, T.; Khan, A.A.; Setty, M.; Rondou, P.; Vandenberghe, P.; et al. A cooperative microRNA-tumor suppressor gene network in acute T-cell lymphoblastic leukemia (T-ALL). Nat. Genet. 2011, 43, 673-678. [CrossRef] [PubMed]

59. Zhao, F.-Y.; Han, J.; Chen, X.-W.; Wang, J.; Wang, X.-D.; Sun, J.-G.; Chen, Z.-T. MiR-223 enhances the sensitivity of non-small cell lung cancer cells to erlotinib by targeting the insulin-like growth factor-1 receptor. Int. J. Mol. Med. 2016, 38, 183-191. [CrossRef] 
60. Tachibana, H.; Sho, R.; Takeda, Y.; Zhang, X.; Yoshida, Y.; Narimatsu, H.; Otani, K.; Ishikawa, S.; Fukao, A.; Asao, H.; et al. Circulating miR-223 in Oral Cancer: Its Potential as a Novel Diagnostic Biomarker and Therapeutic Target. PLoS ONE 2016, 11, e0159693. [CrossRef]

61. Petrocca, F.; Visone, R.; Onelli, M.R.; Shah, M.H.; Nicoloso, M.; de Martino, I.; Iliopoulos, D.; Pilozzi, E.; Liu, C.-G.; Negrini, M.; et al. E2F1-Regulated MicroRNAs Impair TGF $\beta$-Dependent Cell-Cycle Arrest and Apoptosis in Gastric Cancer. Cancer Cell. 2008, 13, 272-286. [CrossRef] [PubMed]

62. Wei, Y.; Yang, J.; Yi, L.; Wang, Y.; Dong, Z.; Liu, Z.; Ou-Yang, S.; Wu, H.; Zhong, Z.; Yin, Z.; et al. MiR-223-3p targeting SEPT6 promotes the biological behavior of prostate cancer. Sci. Rep. 2014, 4, 7546. [CrossRef] [PubMed]

63. Enagpal, N.; Kulshreshtha, R. MiR-191: An emerging player in disease biology. Front. Genet. 2014, 5, 99. [CrossRef]

64. Wu, L.; Li, H.; Jia, C.Y.; Cheng, W.; Yu, M.; Peng, M.; Zhu, Y.; Zhao, Q.; Dong, Y.W.; Shao, K.; et al. MicroRNA-223 regulates FOXO1 expression and cell proliferation. FEBS Lett. 2012, 586, 1038-1043. [CrossRef]

65. Shi, X.; Yan, C.; Liu, B.; Yang, C.; Nie, X.; Wang, X.; Zheng, J.; Wang, Y.; Zhu, Y. MiR-381 Regulates Neural Stem Cell Proliferation and Differentiation via Regulating Hes1 Expression. PLOS ONE 2015, 10, e0138973. [CrossRef]

66. Najafi, Z.; Sharifi, M.; Javadi, G. Degradation of miR-21 induces apoptosis and inhibits cell proliferation in human hepatocellular carcinoma. Cancer Gene Ther. 2015, 22, 530-535. [CrossRef]

67. Guz, M.; Rivero-Müller, A.; Okoń, E.; Stenzel-Bembenek, A.; Polberg, K.; Słomka, M.; Stepulak, A. MicroRNAs-Role in Lung Cancer. Dis. Markers. 2014, 2014, 218169. [CrossRef]

68. Xu, Y.; Sengupta, T.; Kukreja, L.; Minella, A.C. MicroRNA-223 Regulates Cyclin E Activity by Modulating Expression of F-box and WD-40 Domain Protein 7. J. Biol. Chem. 2010, 285, 34439-34446. [CrossRef]

69. Cells, A.T.L.; Moles, R.; Bellon, M.; Nicot, C. STAT1: A Novel Target of miR-150 and miR-223 Is Involved in the Proliferation of HTLV-I-Transformed. Neoplasia 2015, 17, 449-462. [CrossRef]

70. Yang, W.; Lan, X.; Li, D.; Li, T.; Lu, S. MiR-223 targeting MAFB suppresses proliferation and migration of nasopharyngeal carcinoma cells. BMC Cancer. 2015, 15, 461. [CrossRef]

71. Li, J.; Guo, Y.; Liang, X.; Sun, M.; Wang, G.; De, W.; Wu, W. MicroRNA-223 functions as an oncogene in human gastric cancer by targeting FBXW7 / hCdc4. J Cancer Res Clin Oncol. 2012, 138, 763-774. [CrossRef] [PubMed]

72. Hsieh, C.-H.; Cheng, L.-H.; Hsu, H.-H.; Ho, T.-J.; Tu, C.-C.; Lin, Y.-M.; Chen, M.-C.; Tsai, F.-J.; Hsieh, Y.-L.; Huang, C.-Y. Apicidin-Resistant HA22T Hepatocellular Carcinoma Cells strongly activated the Wnt/ $\beta$-Catenin Signaling Pathway and MMP-2 Expression via the IGF-IR/PI3K/Akt Signaling Pathway Enhancing Cell Metastatic Effect Apicidin-Resistant HA22T Hepatocellular. Biosci. Biotechnol. Biochem. 2013, 77, 2397-2404. [CrossRef] [PubMed]

73. Li, H.; Xu, L.; Li, C.; Zhao, L.; Ma, Y.; Zheng, H.; Li, Z.; Zhang, Y.; Wang, R.; Liu, Y.; et al. Ubiquitin ligase Cbl-b represses IGF-I-induced epithelial mesenchymal transition via ZEB2 and microRNA-200c regulation in gastric cancer cells. Mol. Cancer. 2014, 13, 136. [CrossRef]

74. Jia, C.Y.; Li, H.H.; Zhu, X.C.; Dong, Y.W.; Fu, D.; Zhao, Q.L.; Wu, W.; Wu, X.Z. MiR-223 Suppresses Cell Proliferation by Targeting IGF-1R. PLoS ONE 2011, 6, e27008. [CrossRef]

75. Zhang, W.; Ji, W.; Liu, X.; Ouyang, G.; Xiao, W. ELL Inhibits E2F1 Transcriptional Activity by Enhancing E2F1 Deacetylation via Recruitment of Histone Deacetylase 1. Mol. Cell. Biol. 2014, 34, 765-775. [CrossRef]

76. Pulikkan, J.A.; Dengler, V.; Peramangalam, P.S.; Peer Zada, A.A.; Müller-Tidow, C.; Bohlander, S.K.; Tenen, D.G.; Behre, G. Cell-cycle regulator E2F1 and microRNA-223 comprise an autoregulatory negative feedback loop in acute myeloid leukemia. Blood 2010, 115, 1768-1779. [CrossRef] [PubMed]

77. Kaddar, T.; Rouault, J.-P.; Chien, W.W.; Chebel, A.; Gadoux, M.; Salles, G.; Ffrench, M.; Magaud, J.-P. Two new miR-16 targets: Caprin-1 and HMGA1, proteins implicated in cell proliferation. Biol. Cell 2009, 101, 511-524. [CrossRef]

78. Wang, B.; David, M.D.; Schrader, J.W. Absence of Caprin-1 Results in Defects in Cellular Proliferation. J. Immunol. 2005, 175, 4274-4282. [CrossRef] [PubMed]

79. Li, S.; Li, Z.; Guo, F.; Qin, X.; Liu, B.; Lei, Z.; Song, Z.; Sun, L.; Zhang, H.-T.; You, J.; et al. miR-223 regulates migration and invasion by targeting Artemin in human esophageal carcinoma. J. Biomed. Sci. 2011, 18, 24. [CrossRef]

80. Li, B.-S.; Zhao, Y.-L.; Guo, G.; Li, W.; Zhu, E.-D.; Luo, X.; Mao, X.-H.; Zou, Q.-M.; Yu, P.-W.; Zuo, Q.-F.; et al. Plasma microRNAs, miR-223, miR-21 and miR-218, as Novel Potential Biomarkers for Gastric Cancer Detection. PLoS ONE 2012, 7, e41629. [CrossRef]

81. Habbe, N.; Koorstra, J.-B.M.; Mendell, J.T.; Offerhaus, G.J.; Ryu, J.K.; Feldmann, G.; Mullendore, M.E.; Goggins, M.G.; Hong, S.-M.; Maitra, A. MicroRNA miR-155 is a biomarker of early pancreatic neoplasia. Cancer Biol. Ther. 2009, 8, 340-346. [CrossRef]

82. Gomes, C.; Almeida, A.; Ferreira, J.A.; da Silva, M.L.S.; Santos-Sousa, H.; Pinto-De-Sousa, J.; Santos, L.L.; Amado, F.; Schwientek, T.; Levery, S.B.; et al. Glycoproteomic Analysis of Serum from Patients with Gastric Precancerous Lesions. J. Proteome Res. 2013, 12, 1454-1466. [CrossRef]

83. Aziz, F.; Yang, X.; Wang, X.; Qiu, Y. Helicobacter Pylori infection leads to gastric cancer with the co-expression of Lewis Y and CA724. Glycoconj J. 2013, 30, 411.

84. Chang, P.-Y.; Chen, C.-C.; Chang, Y.-S.; Tsai, W.-S.; You, J.-F.; Lin, G.-P.; Chen, T.; Chen, J.-S.; Chan, E.-C. MicroRNA-223 and microRNA-92a in stool and plasma samples act as complementary biomarkers to increase colorectal cancer detection. Oncotarget 2016, 7, 10663-10675. [CrossRef] [PubMed]

85. Aziz, F.; Gao, W.; Yan, Q. Fucosyltransferase-4 and Oligosaccharide Lewis Y Antigen as potentially Correlative Biomarkers of Helicobacter pylori CagA Associated Gastric Cancer. Pathol. Oncol. Res. 2017, 23, 173-179. [CrossRef] [PubMed] 
86. Aziz, F.; Wang, X.; Liu, J.; Yan, Q. Ginsenoside Rg3 induces FUT4-mediated apoptosis in H. pylori CagA-treated gastric cancer cells by regulating SP1 and HSF1 expressions. Toxicol In Vitro. 2016, 31, 158-166. [CrossRef] [PubMed]

87. Aziz, F.; Yang, X.; Wang, X.; Yan, Q. Anti-LeY antibody enhances therapeutic efficacy of celecoxib against gastric cancer by downregulation of MAPKs/COX-2 signaling pathway: Correlation with clinical study. J. Cancer Res. Clin. Oncol. 2015, 141, 1221-1235. [CrossRef] [PubMed]

88. Aziz, F.; Chen, X.; Yang, X.; Yan, Q. Prevalence and Correlation with Clinical Diseases of Helicobacter pylori cagAandvacAGenotype among Gastric Patients from Northeast China. BioMed Res. Int. 2014, 2014, 142980. [CrossRef] [PubMed]

89. Sibley, C.R.; Seow, Y.; Wood, M.J.A. Novel RNA-based Strategies for Therapeutic Gene Silencing. Mol. Ther. 2010, 18, 466-476. [CrossRef]

90. Gao, C.; Cheng, X.; Li, X.; Tong, B.; Wu, K.; Liu, Y. Prognostic significance of artemin and GFR $\alpha 1$ expression in laryngeal squamous cell carcinoma. Exp. Ther. Med. 2014, 8, 818-822. [CrossRef]

91. Escobar, G.; Gentner, B.; Naldini, L.; Mazzieri, R. Engineered tumor-infiltrating macrophages as gene delivery vehicles for interferon- $\alpha$ activates immunity and inhibits breast cancer progression. OncoImmunology 2014, 3, e28696. [CrossRef]

92. Iliescu, L.; Mindrut, E.; Grasu, M.; Orban, C.; Tanase, A.; Toma, L. Management of Hepatocellular Carcinoma-Experience of a Single Center. Chirurgia 2014, 109, 204-207. [CrossRef] [PubMed]

93. Xu, J.; Wu, C.; Che, X.; Wang, L.; Yu, D.; Zhang, T.; Huang, L.; Li, H.; Tan, W.; Wang, C.; et al. Circulating MicroRNAs, miR-21, miR-122, and miR-223, in patients with hepatocellular carcinoma or chronic hepatitis. Mol. Carcinog. 2011, 50, 136-142. [CrossRef] [PubMed]

94. Karakatsanis, A.; Papaconstantinou, I.; Gazouli, M.; Lyberopoulou, A.; Polymeneas, G.; Voros, D. Expression of microRNAs, miR-21, miR-31, miR-122, miR-145, miR-146a, miR-200c, miR-221, miR-222, and miR-223 in patients with hepatocellular carcinoma or intrahepatic cholangiocarcinoma and its prognostic significance. Mol. Carcinog. 2013, 303, 297-303. [CrossRef]

95. Pratedrat, P.; Chuaypen, N.; Nimsamer, P.; Payungporn, S.; Pinjaroen, N.; Sirichindakul, B.; Tangkijvanich, P. Diagnostic and prognostic roles of circulating miRNA-223-3p in hepatitis B virus-related hepatocellular carcinoma. PLoS ONE 2020, 15, e0232211. [CrossRef] [PubMed]

96. Yang, Y.; Jiang, Z.; Ma, N.; Wang, B.; Liu, J.; Zhang, L.; Gu, L. MicroRNA-223 Targeting STIM1 Inhibits the Biological Behavior of Breast Cancer. Cell. Physiol. Biochem. 2018, 45, 856-866. [CrossRef] [PubMed]

97. Chen, L.; Zhu, X.; Han, B.; Ji, L.; Yao, L.; Wang, Z. High Expression of microRNA-223 Indicates a Good Prognosis in Triple-Negative Breast Cancer. Front. Oncol. 2021, 11, 630432. [CrossRef] [PubMed]

98. Su, X.-D.; Zhang, D.-K.; Zhang, X.; Lin, P.; Long, H.; Rong, T.-H. Prognostic factors in patients with recurrence after complete resection of esophageal squamous cell carcinoma. J. Thorac. Dis. 2014, 6, 949-957. [CrossRef] [PubMed]

99. Ikeda-Miyagawa, Y.; Kobayashi, K.; Yamanaka, H.; Okubo, M.; Wang, S.; Dai, Y.; Yagi, H.; Hirose, M.; Noguchi, K. Peripherally Increased Artemin is a Key Regulator of TRPA1/V1 Expression in Primary Afferent Neurons. Mol. Pain. 2015, 11, 8-13. [CrossRef]

100. Ding, K.; Banerjee, A.; Tan, S.; Zhao, J.; Zhuang, Q.; Li, R.; Qian, P.; Liu, S.; Wu, Z.-S.; Lobie, P.E.; et al. Artemin, a Member of the Glial Cell Line-derived Neurotrophic Factor Family of Ligands, Is HER2-regulated and Mediates Acquired Trastuzumab Resistance by Promoting Cancer Stem Cell-like Behavior in Mammary Carcinoma Cells. J. Biol. Chem. 2014, $289,16057-16071$. [CrossRef]

101. Kang, J.; Perry, J.K.; Pandey, V.; Fielder, G.C.; Mei, B.; Qian, P.X.; Wu, Z.S.; Zhu, T.; Liu, D.X.; Lobie, P.E. Artemin is oncogenic for human mammary carcinoma cells. Oncogen.e 2009, 28, 2034-2045. [CrossRef] [PubMed]

102. Wu, C.; Li, M.; Hu, C.; Duan, H. Clinical significance of serum miR-223, miR-25 and miR-375 in patients with esophageal squamous cell carcinoma. Mol. Biol. Rep. 2014, 41, 1257-1266. [CrossRef] [PubMed]

103. Khandwala, H.M.; McCutcheon, I.E.; Flyvbjerg, A.; Friend, K.E.; Osteosarcoma, A. The Effects of Insulin-Like Growth Factors on Tumorigenesis and Neoplastic Growth. Endocr. Rev. 2000, 21, 215-244. [CrossRef] [PubMed]

104. D'Antona, P.; Cattoni, M.; Dominioni, L.; Poli, A.; Moretti, F.; Cinquetti, R.; Gini, E.; Daffrè, E.; Noonan, U.M.; Imperatori, A.; et al. Serum miR-223: A Validated Biomarker for Detection of Early-Stage Non-Small Cell Lung Cancer. Cancer Epidemiol. Biomark. Prev. 2019, 28, 1926-1933. [CrossRef] [PubMed] 